\title{
The Main Character's Construction and the Critique of Capitalism in the Film Deux Jours, Une Nuit
}

\author{
$1^{\text {st }}$ Muhammad Evan Alwin \\ French Department, Faculty of \\ Humanities, \\ Universitas Indonesia, \\ Depok, Indonesia \\ evanalwin@gmail.com
}

\author{
$2^{\text {nd }}$ Joesana Tjahjani* \\ French Department, Faculty of \\ Humanities, \\ Universitas Indonesia, \\ Depok, Indonesia \\ joesana.tjahjani@ui.ac.id
}

\begin{abstract}
The economic crisis that hit Europe in 2008 had a significant impact on the industrial sector, especially among the working class. The effects of this particular crisis have been depicted in many literary works such as writings, films, and music. Thus, the present article analyzes the main character's construction and the critique of capitalism in the 2014 Belgian film titled, Deux Jours, Une Nuit. Moreover, it examines the narrative and cinematographic aspects, and then correlates them with the Marxist critique of capitalism in order to explain the main character's struggle to secure her job. According to the findings, the film not only depicts how the ethics of capitalism influence the working class, but also how they consider humans as an exploitable resource. Such issues related to the economy and society are still found today among the working class, both in Europe and around the world.
\end{abstract}

Keywords-working class, Belgian film, the ethics of capitalism, women in the workplace

\section{INTRODUCTION}

As a cultural product, films can serve as an effective medium for delivering important messages and depicting ongoing issues in the world through their emotive, cinematographic, and narrative contents [1]. It is also impossible to separate films from the socio-cultural aspects underlying their production. In this regard, Belgian filmmakers, such as Jean-Jacques Andrien, Thierry Michel, and the Dardenne brothers (Luc and Jean-Pierre), have made social issues the themes of their works. Such issues have included the concerns and implications due to the weakening of the industrial and agricultural sectors in Europe over the past half century and the increasing number of immigrants.

For example, the 2014 film by the Dardenne brothers titled, Deux Jours, Une Nuit (literally translated as Two Days, One Night), shows how issues related to the economy and society have a direct impact on the main character. This award-winning, 95-minute film tells the story of Sandra Bya (Marion Cotillard), who prepares to return to work following a leave of absence for her depression and anxiety. However, a supervisor realizes that Sandra's work can be effectively covered by 16 of her co-workers, after which he decides to dismiss her and offer each worker a $€ 1000$ bonus. After a vote is held, 14 out of the 16 workers agree to dismiss Sandra. Subsequently, in her attempt to make ends meet and keep her job, Sandra asks for a re-vote. Over the next two days and one night, she convinces enough workers to side with her and not the bonus.
Due to its subject matter, numerous studies have focused on this particular film. For example, in the article titled, "A Working-Class Tale of Embodiment and Belonging: Two Days, One Night," Christopher Baum explained how the character of Sandra becomes the embodiment of the working class and experiences oppression due to the practices of neoliberalism. Meanwhile, Robert Watkins [2], in his article titled, "Turning the Social Contract Inside Out: Neoliberal Governance and Human Capital in Two Days, One Night," explained how the character of Sandra is placed in the situation between social contract and neoliberalism. In contrast to the article titled, "Creativité organizationelle et politique dans le cinéma des Frères Dardenne," Nicole D'Almeida [3] described how the film depicts the working world through various issues. Another study that used the film as a corpus was "Weekend as Community, Consumption, and Colonization: Struggles over Liminal Time in Two Days, One Night" by Gazi Islam [4]. More specifically, this article described the concept of the weekend, which acts as a catharsis for the working class. Interestingly, the common keyword among the aforementioned studies is "working class." This also indicates that the role of the economy in society is still relevant, especially regarding the welfare of the working class in Europe and around the world

\section{METHOD}

This article, based on the qualitative method and the film studies approach, first scrutinizes the narrative and cinematographic aspects (e.g., plot, characters, settings, and audio and visual aspects) of Deux Jours, Une Nuit. Previous research has shown that such aspects have the ability to represent imagination and feelings [1]. However, a literary work must refer to the reality and phenomena that exist in real life [5]. Then, it correlates these aspects with the Marxist critique of capitalism (which states that the owners of the means of production generally exploit the workforce) in order to explain the main character's dilemma.

\section{RESULTS AND DISCUSSION}

For the purpose of this article, the film is divided into 36 sequences that support the main idea through their narrative and cinematographic aspects. One of the longest sequences is the first one, which includes Sandra's dismissal and triggers the subsequent events that drive the storyline. As the main character, Sandra appears in all 36 sequences, followed by her husband Manu (Fabrizio Rongione), who appears in 21 sequences. In the film, the young couple recently purchased a house and must work in order to pay the mortgage and meet their daily needs. In addition to Sandra and Manu, the other 
characters include Sandra's co-workers, who are divided into those who accepted the $€ 1000$ bonus and those who refused her pleas. Interestingly, no effort is made to build hatred or support toward the co-workers. Instead, they are simply depicted with their respective problems in terms of rejecting or accepting Sandra's pleas.

Both the narrative and cinematographic aspects of the film support the main idea. For instance, the camera always follows Sandra, which creates a sense of realism for viewers. In addition, the use of a hand-held camera and the balance between shaky/uneven and stable camera work (especially in the shots of Sandra and her co-workers), enhance the dramatic effects and create tension in the film. As for the framing of the film, it is consistent, since the characters are never shown larger or smaller in proportion, and they are always standing face-to-face. Meanwhile, the lighting does not depict the characters in different positions. Overall, this mise-en-scene has significance in the meaning of the storyline and the cinematographic aspects can be understood as the directors' way of showing the similarities of Sandra and her co-workers in regard to various work-related and personal matters.

In general, a literary work takes form as a socio-cultural document, which can be used to understand phenomena in society. According to Laurenson and Swingewood [5], a literary work is a direct reflection of various aspects of social structure, family relationships, class conflicts, other trends that may arise, and population composition. Although it certainly contains the imagination of the author, a literary work must refer to the reality and phenomena that exist in real life [5]. In this regard, the film is set in the city of Seraing, Belgium, which is a relatively quiet, small town that has experienced the ups and downs of the region's economy. In fact, the area around the city has had a high unemployment rate since the grève générale de l'hiver (literally translated as "general strike") during the winter of 1960-1961 [6]. These long-term social issues have become collectively embedded in the minds of the people and those of Belgian filmmakers. For example, the Dardenne brothers, both of whom grew up in the Walloon Region, make such social issues the main themes of their works.

Back in 2008, the world was hit by an economic crisis, which resulted in a global recession. It also severely impacted industrial and trade activities, one of the benchmarks for measuring the economy of a country/region [7]. The consequences of this crisis, such as high unemployment and low incomes, have since been accepted by the industrial world. In fact, when faced with a similar crisis in the latter half of the 2010s, many companies established policies that directly affected their workers. Such policies included reducing salaries, adjusting the number of work hours or dismissing employees altogether. However, in Europe, such policies only aggravated the crisis, since it significantly impacted the daily lives of workers and in some cases, increased the overall rate of unemployment [8].

As for the Belgian population, the unemployment rate in the province of Liège is $23 \%$, one of the highest in the country. In regard to the economic crisis in 2008, this province experienced a more severe crisis than the Flanders region in Belgium [9]. Such unemployment indicators are shown in the film's final sequence in which Manu addresses his concerns about Sandra finding other work.

Overall, the film Deux Jours, Une Nuit presents a storyline that highlights the social and economic conditions of the working class. The problems faced by Sandra and her co-workers are typical of middle-class workers, especially those whose daily lives are preoccupied with earning a living. The context of laborers certainly cannot be separated from those who employ them. This broad understanding of capitalism is depicted in the film by how the company attempts to seek as much profit as possible by exploiting the laborers.

The concept of Karl Marx's critique of capitalism can be juxtaposed with Sandra's character. In his view, the dynamic of capital will eventually impoverish the working class and thereby create the social conditions for a revolution. In addition, private ownership over the means of production and distribution creates a dependence of the non-owning classes on the ruling class, which ultimately restricts their freedom [10]. In this case, Solwal, the company in which Sandra is employed, treats its workers as a commodity and does not consider them to be human.

Solwal is also forced to make a decision to dismiss Sandra for efficiency reasons. More specifically, Jean-Marc, the supervisor, sees potential savings if he is able to reduce one worker and add a few hours of work to the others. This can be seen as a conflict between the capital owners and what Marx referred to as "labor power," i.e., workers as humans who only have the capacity to receive wages through physical labor [11]. Interestingly, instead of deciding to dismiss or retain his own worker, the owner of the capital (represented by the Solwal manager, M. Dumont) pits the main character against her co-workers. As stated earlier, Sandra's co-workers preferred the bonuses, instead of saving her job. In this case, their preference was not due to the lack of solidarity, but it was due to the system that urged them to earn more income in order to make ends meet.

Capitalism places the economy as the reason and driver of all aspects in life. It is as if the economy is the antagonist of humanity. Meanwhile, the film depicts the struggle between idealism and pragmatism in decision-making. Idealism, which considers ideals as the only true aspects that can be remembered and understood, is shown in the sense of the solidarity between Sandra and her co-workers. As for pragmatism, which refers to providing useful explanations about a problem by examining its cause and effect, it is shown in what and how decisions are made in the film based on certain interests (e.g., bonuses). Pragmatism, especially in the selection of bonuses, can be said to be highly influenced by the economy.

Returning to the argument that modern society cannot separate the economy from decision-making, the $€ 1000$ bonuses offered to Sandra's co-workers are particularly important. For example, the salaire minimum interprofessionnel de croissance (SMIC) (i.e., the average income in Belgium) is approximately $€ 1,562$, which indicates how important an additional $€ 1000$ is for the working class, especially during the aftermath of the 2008 financial crisis. 
Modern society is also driven by consumption. This was one of the main reasons why the co-workers rejected Sandra and accepted the $€ 1000$ bonuses. Conversely, those who voted to keep Sandra acted as a counter to such capitalist practices. For example, her co-worker Yvon supported Sandra in order to show solidarity and repay her for a favor made in the past. Interestingly, Timur voted to accept the bonus, but broke down in tears about his decision. In another sequence, Anne's willingness to leave her husband in order to support Sandra was a reflection of her true integrity. Meanwhile, Manu's loyalty to Sandra was unwavering throughout the film, as shown when he accompanied her to meet the co-workers and when he provided moral support following her attempted suicide.

In sum, based on the attitudes and actions of Sandra's supportive co-workers, the film Deux Jours, Une Nuit effectively highlights the values of integrity, solidarity, and loyalty. However, these values are not only used to depict the support for the main character, but they are also used to oppose the acts of repression carried out by the company. In this case, capitalism's exploitative and inhuman nature is broken and the importance of human relations is emphasized.

\section{CONCLUSION}

Through its narrative and cinematographic aspects, the film Deux Jours, Une Nuit shows that the ethics of capitalism support the practice of social inequality and consider workers as an exploitable resource. This theme is depicted in the numerous sequences by the main character, Sandra, as she overcomes the various problems that arise. Meanwhile, the cinematographic approach of using shaky/uneven and stable camera work not only enhances the dramatic effects and tension in the film, but it also highlights the similarity of the characters' positions, especially when Sandra and her coworkers deal with various work-related and personal matters.

Moreover, the film presents the main character as a symbol of resistance to the dominance of capitalism and its unethical practices. It also effectively depicts the conditions of women in the workplace, especially regarding how they are discriminated and considered as obstacles, instead of hard workers with determination. Such attitudes are, unfortunately, still apparent in today's society. As a result, gender equality remains a highly discussed topic in the media. Even the United Nations has included it as one of its 17 Sustainable Development Goals.
Overall, this analysis builds awareness that capitalism has a significant impact on society, especially in the economic domain. The elements in this film also help the viewers understand the existence and position of capitalistic practices among the working class. By resonating such elements in the film, the Dardenne brothers emphasize the moral consequences of capitalism and place the question of human relations at its heart. It also shows that money does not compare to the values of integrity, solidarity, and loyalty.

In the end, there was no glorification of the main character's persona. Instead, in her quest to convince enough co-workers to support her, she simply finds the confidence to pursue a new life. This is shown in the final scene, where she proudly tells her husband, "We put up a good fight."

\section{REFERENCES}

[1] Boggs, J. M., \& Petrie, D. W. (2008). The Art of Watching Films ( $^{\text {th }}$ Edition). New York: Mcgraw-Hill.

[2] Watkins, R. (2016). Turning the social contract inside out: neoliberal governance and human capital in Two Days, One Night. The Annual Meeting of The Western Political Science Association.

[3] D'Almeida, N. (2018). Créativité organisationnelle et politique dans le cinéma des Frères Dardenne. 'Questionner le tournant créatif: dispositifs, processus et représentations' (pp. 126-130). Université d'économie de Varna, Bulgaria.

[4] Islam, G. (2016). Weekend as Community, Consumption, and Colonization: Struggles over Liminal Time in Two Days, One Night. M@n@gement: Unplugged-Voices: Two Days, One Night (2014), 19(2), 146-151.

[5] Laurenson, D., \& Swingewood, A. (1972). The sociology of literature. Paladin.

[6] Baum, C. (2015). A working-class tale of embodiment and belonging: two days, one night. New Labor Forum (Vol. 24, No. 3, 102-104). Sage CA: Los Angeles, CA: SAGE Publications.

[7] Outin, J. (2013). Crise financière, crise économique et crise sociale : un enchaînement à hauts risques. Informations sociales, 180(6), 1021.

[8] De Mulder, J., \& Druant, M. (2011). Le marché belge du travail pendant et après la crise. Revue économique, 91-106.

[9] The Economist Intelligence. (2018). Belgium economy: Demographic profile. EIU ViewsWire.

[10] LibreTexts. (2019). The Marxist Critique of Capitalism.

[11] Cobben, P. (2015). Value in capitalist society: Rethinking Marx's criticism of capitalism. Leiden: Brill. 